\title{
Stability Indicating RP-HPLC method development and validation for simultaneous quantification of antihistaminic \& anti-asthmatic drug in bulk and tablet dosage form
}

\author{
Jitendra K. Sonawane', Dilip A. Patil ${ }^{2, *}$, Balasaheb S. Jadhav ${ }^{3}$, Satish L. Jadhav ${ }^{4}$, Prashant B. Patil ${ }^{5}$ \\ 1,2,5 H. R. Patel Institute of Pharmaceutical Education and Research, Shirpur, Maharashtra, ${ }^{3,4}$ Emcure Pharmaceuticals Ltd, \\ Pune, Maharashtra, India
}

*Corresponding Author: Dilip A. Patil

Email: dilipapatil@gmail.com

\begin{abstract}
This research describes the stability indicating RP-HPLC method in pharmaceutical tablet dosage forms for simultaneous estimation of Levocetirizine dihydrochloride (LEV) and Montelukast Sodium (MON). The proposed RP-HPLC method was developed using separation module Waters 2695 with PDA detector and chromatographic separation was performed at a flow rate of $1 \mathrm{~mL} / \mathrm{min}$ using column Hypersil BDS C18 $(250 / 4.6 \mathrm{~mm}, 5 \mu \mathrm{m})$ with a run time of $10 \mathrm{~min}$. The mobile phase consisted of a $40: 60 \% \mathrm{v} / \mathrm{v}$ Phosphate buffer and acetonitrile, $\mathrm{pH}$ with orthophosphoric acid was adjusted to 7.0 and the eluents were scanned at $230 \mathrm{~nm}$ using a PDA detector. Retention times for LEV and MON were $3.06 \mathrm{~min}$, and $6.76 \mathrm{~min}$, respectively. A linearity response was observed with a concentration range of $12.56-37.68 \mu \mathrm{g} / \mathrm{mL}$ for LEV and $23.78-71.20 \mu \mathrm{g} / \mathrm{mL}$ for MON. Limit of detection and limit of quantification for LEV are $0.079 \mu \mathrm{g} / \mathrm{mL}$ and $0.239 \mu \mathrm{g} / \mathrm{mL}$ and for MON are $0.156 \mu \mathrm{g} / \mathrm{mL}$ and $0.473 \mu \mathrm{g} / \mathrm{mL}$, respectively. The stability indicating method was developed by subjecting the drugs to stress conditions such as acid, base hydrolysis, oxidation, neutral, photo- and thermal degradation, and the degraded products produced from the samples were successfully solved.
\end{abstract}

Keywords: Levocetirizine dihydrochloride, Montelukast Sodium, RP-HPLC, stability indicating.

\section{Introduction}

Levocetirizine dihydrochloride (LEV), (2-[4-(R)-(4chlorophenyl) phenylmethyl]-1-piperazinyl]ethoxyacetate dihydrochloride) (fig. 1) is a third-generation non-sedative antihistamine, $\mathrm{H} 1$ receptor antagonist. ${ }^{1-6}$ does block histamine receptors. This is used to treat several allergic reactions, i.e., allergic rhinitis, idiopathic urticaria, hay fever, etc. ${ }^{7}$ The half-dose form of LCTZ $(2.5 \mathrm{mg})$ has been clinically proven to have equivalent antihistaminic effectiveness in the treatment of allergic rhinitis and chronic idiopathic urticaria to the normal amount of cetirizine $(5.0 \mathrm{mg}){ }^{2,8}$<smiles>O=C(O)COCCN1CCN([C@H](c2ccccc2)c2ccc(Cl)cc2)CC1</smiles>

Montelukast Sodium (MON) (1-[[[(1R)-1-[3-(1E)-2(7-chloro-2-quinolinyl) ethenyl] phenyl]-3-[2-(1hydroxy-1-methylethyl) phenyl] -propyl] thio] methyl cyclopropaneacetic acid, monosodium salt (Fig. 2) is a white colored powder which is easily soluble in ethanol, methanol and water and is practically insoluble in acetonitrile. Montelukast Sodium molecular weight is $608.2 \mathrm{~g} / \mathrm{mol}$ and $\mathrm{C}_{35} \mathrm{H}_{35} \mathrm{ClNO}_{3} \mathrm{~S}$.Na is formula. Recent studies have shown that treatment with concomitant administration of anti-leukotriene and antihistamines for allergic rhinitis provides a significantly enhanced symptom relief compared to the mild improvement in rhinitis symptoms with each drug alone., ${ }^{5,9-11}$

Fig. 1: Chemical structure of Levocetirizine dihydrochloride 


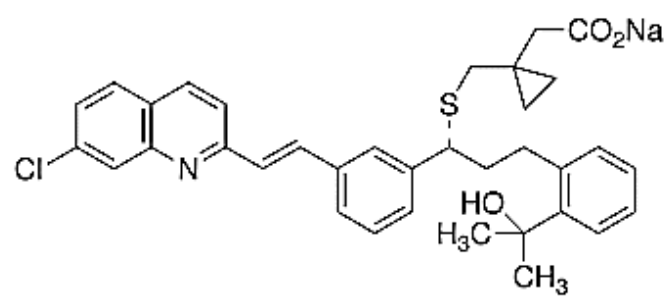

Fig. 2: Chemical structure of Montelukast sodium

The literature survey indicates that various methods have been published for evaluating LEV and MON in single-component formulations, but less methods are available for simultaneous evaluation of these two drugs in multicomponent dosage forms. ${ }^{3,}$ 5,12-16 No analytical methods were reported in the presence of their degrading product for the simultaneous estimation of LEV and MON in bulk, and their combined dosage forms. Therefore, the purpose of this work was to describe a simple, accurate, repeatable and time mitigation RP-HPLC method for the simultaneous determination of LEV and MON in the tablet dosage form and validation of the same as according to $\mathrm{ICH}$ guidelines. ${ }^{17-19}$

\section{Materials and Methodologies}

\section{Chemical and reagents}

The MON and LEV APIs are collected from the company Emcure Pharmaceuticals Ltd. Pune, India as a gift sample. Acetonitrile grade HPLC shall be obtained from Merck (Mumbai, India), HPLC grade Water (Milli Q) for a complete chemical analysis (AR grade). Pharmaceutical tablet dosage form containing $10 \mathrm{mg}+$ $5 \mathrm{mg}$ of Nukast-10 was purchased from local pharmacy.

\section{Instrumentation}

The HPLC experiment is performed on a Waters Alliance 2690 separation module with a Waters 2996 photodiode array detector using an Auto Sampler. Data collection and processing have been prepared using EMPOWER PDA 2 software. The analytical column used for the separation was Hypersil BDS C18, $250 \mathrm{~mm}$ $\times 4.6 \mathrm{~mm}$ Column, $5 \mu \mathrm{m}$, Other equipment's used were ultra-sonicator (Equitron), Single Pan Electronic Balance (Startorious) PH Meter (LABINDIA).

\section{Preparing solutions \\ Buffer}

Mix 2.8 gm of Disodium hydrogen orthophosphate dihydrate in $1000 \mathrm{ml}$ of water, adjust pH-7.0 with OPA.

\section{Mobile phase}

Mix acetonitrile and phosphate buffer with a $\mathrm{pH}-7.0$ ratio of $60: 40$. Filter through $0.45 \mu$ membrane filter paper.

\section{Diluents}

Mobile phase used as diluent.

\section{Preparing a standard solution}

\section{Solution A}

Weigh exactly about $25 \mathrm{mg}$ of Levocetirizine dihydrochloride in a $50 \mathrm{ml}$ volumetric flask. Add $35 \mathrm{ml}$ of diluents, dissolve to sonicate and dilute to volume with the diluents. Transfer $1 \mathrm{ml}$ of the above solution to $20 \mathrm{ml}$ with diluents to make a $25 \mathrm{ppm}$ solution.

\section{Solution B}

Weigh exactly about $50 \mathrm{mg}$ of Montelukast Sodium in a $50 \mathrm{ml}$ volumetric flask. Add $35 \mathrm{ml}$ of diluents, dissolve to sonicate and dilute to volume with the diluents. Transfer $1 \mathrm{ml}$ of the above solution to $20 \mathrm{ml}$ with diluents to make $50 \mathrm{ppm}$ of the solution.

\section{Conditions of chromatography}

The HPLC experiment is performed on the Waters Alliance 2690 Separation Module with the Waters 2996 Photodiode Array Detector using the Auto Sampler. Data collection and analysis was carried out using the EMPOWER PDA 2 software. The analytical column used for the separation was Hypersil BDS C18, $250 \mathrm{~mm}$ $\times 4.6 \mathrm{~mm}, 5 \mu \mathrm{m}$; Other equipment used were ultrasonicator (Equitron), single pan electronic balance (Startorious) PH meter (LABINDIA). Characteristic chromatography of LEV and MON was shown in Fig. 3 and optimized chromatographic conditions as shown in Table 1. 


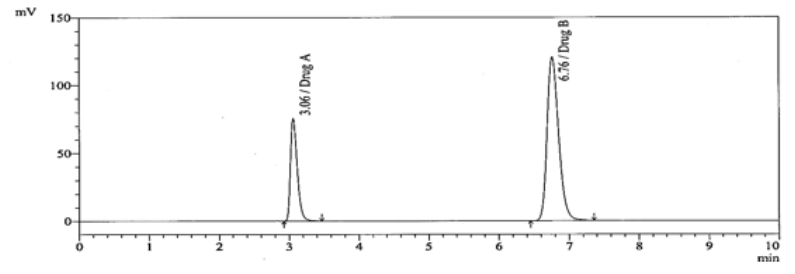

Fig 3: Typical chromatogram of LEV and MON

Table 1: Optimized conditions of chromatography.

\begin{tabular}{|l|l|}
\hline Column & $\begin{array}{l}\text { Hypersil } \\
250 \mathrm{~mm} \times 4.6 \mathrm{~mm}, 5 \mu \mathrm{m}\end{array}$ \\
\hline Mobile phase & $\begin{array}{l}\text { Acetonitrile : Phosphate buffer } \\
\mathrm{pH}-7.0(60: 40)\end{array}$ \\
\hline Flow rate & $1.0 \mathrm{ml} / \mathrm{min}$ \\
\hline Column temperature & $30^{\circ} \mathrm{C}$ \\
\hline Injection Volume & $10 \mu \mathrm{L}$ \\
\hline $\begin{array}{l}\text { Detection } \\
\text { Wavelength }\end{array}$ & $230 \mathrm{~nm}$ \\
\hline Run time & $10 \mathrm{~min}$ \\
\hline Retention time & $3.06(\mathrm{LEV}), 6.76(\mathrm{MON}) \mathrm{min}$ \\
\hline
\end{tabular}

\section{Wavelength selection}

In the Fig. 4 LEV and MON UV spectrum, wavelength $230 \mathrm{~nm}$ showing isobestic radiation, was selected.

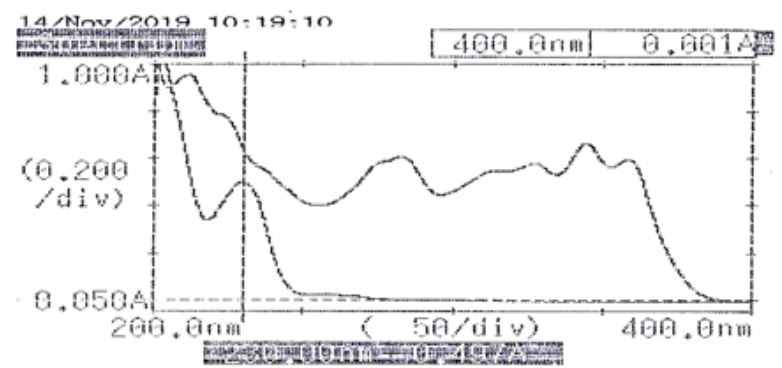

Fig. 4: UV Spectrum of LEV and MON

\section{Development of the method}

To saturate the column, the mobile phase was pumped for about 30 minutes so that the base line could be corrected. Standard calibration lines have been designed for each drug. A series of aliquots were prepared from the above-mentioned stock solutions using diluents to obtain concentrations of 12.56-37.68 $\mu \mathrm{g} / \mathrm{ml}$ for LEV, 23.78-71.20 $\mu \mathrm{g} / \mathrm{ml}$ for MON. Inject each concentration 6 times into the chromatography system. Each time the peak is and the retention time for both drugs has been recorded separately. Calibration curves are constructed as individual for both drugs by taking the average peak area of the $\mathrm{Y}$-axis and the concentration of the $\mathrm{X}$-axis Regression equations was derived from the calibration curves. These regression equations are used in the formulation to measure the content of the product. LEV and MON measured in tablet dosage form.

Weigh 20 tablets and crush to powder, then add powder equivalent to $25 \mathrm{mg}$ of LEV and $50 \mathrm{mg}$ of MON to a $100 \mathrm{ml}$ volumetric flask. Add $70 \mathrm{ml}$ of diluents, sonicate for $10 \mathrm{~min}$ to dissolve the active ingredients and dilute to volume with the diluents. Filter through the Whatman filter paper no. 41 . Then dilute $5 \mathrm{ml}-50$ $\mathrm{ml}$ with the diluents. Filter with $0.45 \mu$ Nylon syringe filter. This solution was estimated using the abovedeveloped method. The assay procedure was repeated 6 times $(n=6)$ the drug content was estimated using the above calculated regression equation; the results of the tablet dosage form are shown in Table 2.

Table 2: Marketed Formulation Analysis Results.

\begin{tabular}{|l|l|l|l|l|l|l|}
\hline $\begin{array}{c}\text { Name of the } \\
\text { compound }\end{array}$ & $\begin{array}{c}\text { Brand } \\
\text { name }\end{array}$ & $\begin{array}{c}\text { Label claim } \\
(\mathbf{m g})\end{array}$ & $\begin{array}{c}\text { Test concentration } \\
(\boldsymbol{\mu g} / \mathbf{m l})\end{array}$ & $\begin{array}{c}\text { Mean amount estimated } \\
(\boldsymbol{\mu} \mathbf{g} / \mathbf{m l})(\mathbf{n}=\mathbf{6})\end{array}$ & $\begin{array}{c}\text { \% } \\
\text { Assay }\end{array}$ & \% RSD \\
\hline LEV & Nukast-10 & $5 \mathrm{mg}$ & 25 & 24.88 & 99.55 & 0.43 \\
\hline MON & & $10 \mathrm{mg}$ & 50 & 49.18 & 98.37 & 0.57 \\
\hline
\end{tabular}

\section{Validation of method}

The method described has been validated for linearity, accuracy, detection limit, precision and robustness, as set out in the ICH guidelines. ${ }^{20}$ 


\section{Linearity}

The linearity of the method was determined by the preparation of six different concentrations of LEV and MON within the 12.56-37.68 $\mu \mathrm{g} / \mathrm{ml}$ and $23.78-71.20 \mu \mathrm{g} / \mathrm{ml}$ concentration ranges. Every solution was prepared in a triplicate. Plotting peak area against concentration was used to obtain the calibration curve. Linearity was tested over the same concentration range over three consecutive days and results were obtained. Results have been shown in Table 3a-3c and graphs shown in Figure 5 A-B.

Table 3a: Linearity studies of LEV.

\begin{tabular}{|c|c|c|}
\hline S. No. & Concentration $(\boldsymbol{\mu g} / \mathbf{m l})$ & Average peak area \\
\hline 1. & 0 & 0 \\
\hline 2. & 12.56 & 251813 \\
\hline 3. & 18.84 & 368600 \\
\hline 4. & 25.12 & 495138 \\
\hline 5. & 31.40 & 616357 \\
\hline 6. & 37.68 & 744210 \\
\hline
\end{tabular}

Table 3b: Linearity studies of MON.

\begin{tabular}{|c|c|c|}
\hline S. No. & Concentration $(\boldsymbol{\mu g} / \mathbf{m l})$ & Average peak area \\
\hline 1. & 0 & 0 \\
\hline 2. & 23.73 & 680965 \\
\hline 3. & 35.60 & 997397 \\
\hline 4. & 47.47 & 1338187 \\
\hline 5. & 59.34 & 1667722 \\
\hline 6. & 71.20 & 2012095 \\
\hline
\end{tabular}

Table 3c: LEV and MON optical characteristics

\begin{tabular}{|l|l|l|}
\hline \multicolumn{1}{|c|}{ Parameters } & \multicolumn{1}{c|}{ LEV } & \multicolumn{1}{c|}{ MON } \\
\hline Linearity range $(\mu \mathrm{g} / \mathrm{ml})$ & $12.56-37.68$ & $23.73-71.20$ \\
\hline Regression equation & $\mathrm{y}=19624.05 \mathrm{x}+2203.20$ & $\mathrm{y}=28082.68 \mathrm{x}+6239.20$ \\
\hline Slope & 19624.05 & 28082.68 \\
\hline Intercept & 2203.20 & 6239.20 \\
\hline Correlation coefficient $\left(\mathrm{R}^{2}\right)$ & 0.9998 & 0.9998 \\
\hline
\end{tabular}
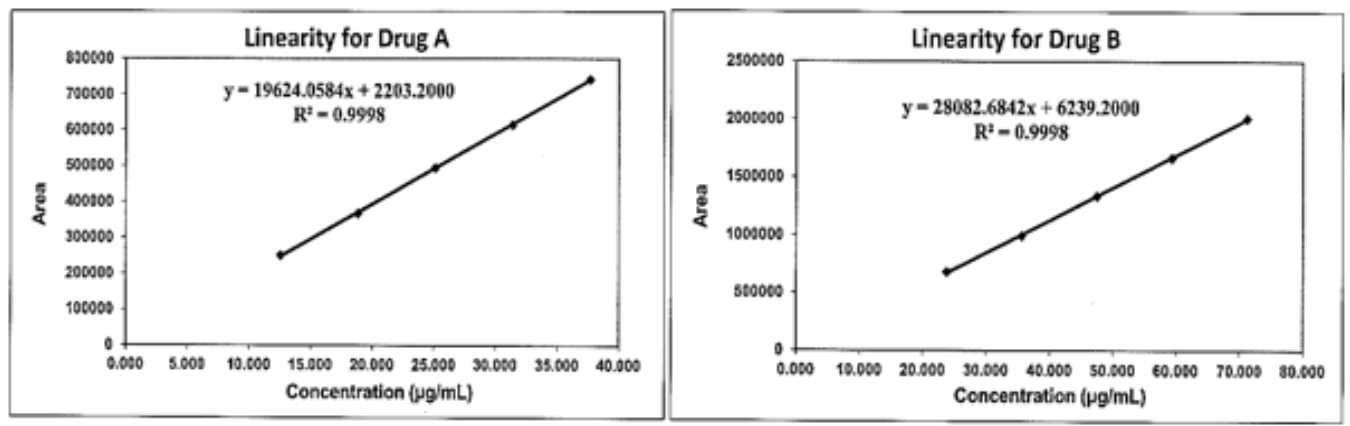

Fig. 5: Linearity of the plot A) Levocetirizine dihydrochloride B) Montelukast sodium.

Accuracy, as recovery

The accuracy of the method was determined at three different concentration levels: $50 \%, 100 \%$, and $150 \%$ of the known amount of drug analyte, and a \% of recovery was calculated. And the results have been shown in Table 4. 
Table 4: LEV and MON recovery studies.

\begin{tabular}{|c|c|c|c|c|c|c|}
\hline Drug & $\begin{array}{c}\text { \% Recovery } \\
\text { level }\end{array}$ & $\begin{array}{c}\text { Pre-analyzed } \\
\text { conc }(\boldsymbol{\mu g} / \mathbf{m l})\end{array}$ & $\begin{array}{c}\text { Known amount } \\
\text { added }(\boldsymbol{\mu g} / \mathbf{m l})\end{array}$ & $\begin{array}{c}\text { Amounts } \\
\text { found }(\boldsymbol{\mu g} / \mathbf{m l})\end{array}$ & $\begin{array}{c}\text { \% } \\
\text { Recovery }\end{array}$ & \% RSD \\
\hline \multirow{3}{*}{ LEV } & $50 \%$ & 31.30 & 15.66 & 15.81 & 100.96 & 0.10 \\
\cline { 2 - 7 } & $100 \%$ & 31.30 & 31.30 & 31.09 & 99.33 & 0.13 \\
\cline { 2 - 7 } & $150 \%$ & 31.30 & 46.94 & 46.69 & 99.47 & 0.15 \\
\hline \multirow{2}{*}{ MON } & $50 \%$ & 62.50 & 31.25 & 31.26 & 100.03 & 0.26 \\
\cline { 2 - 7 } & $100 \%$ & 62.50 & 62.51 & 61.33 & 98.11 & 0.33 \\
\cline { 2 - 7 } & $150 \%$ & 62.50 & 93.75 & 92.57 & 98.74 & 0.40 \\
\hline
\end{tabular}

\section{Precision}

\section{Precision of the method (Repeatability)}

The precision method is determined by injecting six working standard solutions and six sample injections. The areas of all injections were taken and the standard deviation, \% relative standard deviation (RSD), \% assay was calculated.

\section{Intermediate precision}

The intermediate precision was determined by injecting six working standard solutions and six sample injections on different days by different operators or by different instruments. All injection areas were taken and the standard deviation, \% relative standard deviation (RSD), \% assay was calculated. The results were shown in Tables 5a and b.

Table 5a: Method Precision studies for LEV and MON.

\begin{tabular}{|c|c|c|}
\hline S. No & LEV & MON \\
\hline 1 & 502621 & 1364588 \\
\hline 2 & 501951 & 1361227 \\
\hline 3 & 501602 & 1365023 \\
\hline 4 & 501735 & 1365080 \\
\hline 5 & 499351 & 1361537 \\
\hline 6 & 501702 & 1365123 \\
\hline Mean & 501494 & 1363763 \\
\hline Standard deviation & 1112.2 & 1856.8 \\
\hline \%RSD & 0.22 & 0.14 \\
\hline
\end{tabular}

Table 5b: System Precision studies for LEV and MON

\begin{tabular}{|c|c|c|}
\hline S. No & LEV & MON \\
\hline 1 & 502437 & 1354588 \\
\hline 2 & 499864 & 1361277 \\
\hline 3 & 500123 & 1375023 \\
\hline 4 & 499475 & 1369080 \\
\hline 5 & 498537 & 1341567 \\
\hline 6 & 501679 & 1362123 \\
\hline Mean & 500353 & 1360605 \\
\hline Standard deviation & 1446.5 & 11681.2 \\
\hline \%RSD & 0.28 & 0.85 \\
\hline
\end{tabular}




\section{Limit of detection (LOD) and Limit of quantification (LOQ)}

\section{$L O D$}

It is the lowest amount of analyte in the sample that can be detected but not necessarily quantified as an exact value in the experimental conclusions. The detection limit is usually expressed as an analytical concentration. The standard deviation and the slope response and the results obtained. LOD $=3.3^{*} \mathrm{~S} / \mathrm{N} \mathrm{S} / \mathrm{N}$.

$L O Q$

The quantitative limit of the analytical procedure is the lowest amount of the sample analyte that can be quantitatively determined with appropriate precision and accuracy. The standard deviation and the slope response and the results obtained. And the results have been shown in Table $6 . \mathrm{LOQ}=10 \mathrm{~S} / \mathrm{N}$.

Table 6: LOD and LOQ for LEV and MON.

\begin{tabular}{|c|c|c|}
\hline & LEV & MON \\
\hline LOD $(\mu \mathrm{g} / \mathrm{ml})$ & 0.079 & 0.156 \\
\hline LOQ $(\mu \mathrm{g} / \mathrm{ml})$ & 0.239 & 0.473 \\
\hline
\end{tabular}

\section{Parameters of system suitability}

In order to assess system suitability, six replicates of working standards samples of Ledipasvir and Sofosbuvir were injected and parameters such as plate number $(\mathrm{N})$, tailing factor $(\mathrm{K})$, resolution, relative retention time and peak sample asymmetry were studied. The results have been tabulated in Table 7.

Table 7: System suitability parameters for LEV and MON

\begin{tabular}{|l|c|c|c|}
\hline \multicolumn{1}{|c|}{ Parameter } & LEV & MON & Criteria for acceptance \\
\hline Retention time & 3.03 & 6.79 & For information \\
\hline Plate count & 37873 & 71635 & NLT 2000 \\
\hline Tailing factor & 1.25 & 1.17 & NMT 2 \\
\hline Resolution & 5.49 & 5.14 & NLT 1.5 \\
\hline
\end{tabular}

\section{Robustness}

The robustness of the assay method was calculated by adding minor chromatographic changes, including wavelength $(228 \mathrm{~nm}-232 \mathrm{~nm})$, flow rate $(0.9$ and $1.1 \mathrm{~mL} / \mathrm{min})$ and $\mathrm{pH}(+0.2 \%$ to $-0.2 \%)$. The findings have been tabulated in Table 8 .

Table 8: Robustness studies for LEV and MON

\begin{tabular}{|c|c|c|c|c|c|c|c|}
\hline \multicolumn{2}{|c|}{ Method parameters } & Conditions & \multicolumn{2}{|c|}{ Retention Time $\left(\mathbf{R}_{\mathbf{t}}\right)$} & \multicolumn{2}{c|}{ Area } & \multicolumn{2}{c|}{ \%Recovery } \\
\hline \multicolumn{2}{|c|}{} & LEV & MON & LEV & MON & LEV & MON \\
\hline Flow + & +0.1 & 2.97 & 6.67 & 560587 & 1592893 & 101.56 & 100.87 \\
\hline Flow - & -0.1 & 3.84 & 8.60 & 458881 & 1304626 & 101.66 & 101.01 \\
\hline $\mathrm{pH}+$ & +0.2 & 2.52 & 5.64 & 510992 & 1456552 & 102.41 & 101.75 \\
\hline $\mathrm{pH}-$ & -0.2 & 3.76 & 8.84 & 508326 & 1442763 & 101.86 & 101.27 \\
\hline Wavelength + & +2 & 3.01 & 6.74 & 494758 & 1536167 & 101.74 & 101.06 \\
\hline Wavelength - & -2 & 2.87 & 6.43 & 498481 & 1363403 & 101.84 & 101.17 \\
\hline
\end{tabular}

\section{Selectivity and specificity}

Specificity is the level to which the technique applies to a single analyte, and is tested for any interfering peaks in each study by analysing blank matrix samples. The specificity of the method was evaluated for interference due to the presence of any other placebos. Two separate samples were injected and tested with placebos, respectively. The HPLC chromatograms reported for 
the drug matrix (drug mixture and placebos) showed nearly no interfering peaks with time ranges in retention.

\section{Forced degrading studies}

Forced drug formulation degradation studies have been conducted to treat drug samples under stress-induced conditions such as acid and base hydrolysis, oxidation, photo-and thermal degradation and interference of degraded products. These studies help to determine the inherent stability of the effective molecules in the drug product and the potential degradation products..$^{21,22}$

\section{Preparing of sample stock solution}

For forced degradation studies, the powder sample was carefully weighed equivalent to $25 \mathrm{mg}$ of LEV and 50 $\mathrm{mg}$ of MON and transferred to a $100 \mathrm{ml}$ volumetric flask containing $70 \mathrm{ml}$ of diluent, dissolving sonicate for $10 \mathrm{~min}$.

\section{Studies on Acid degradation (0.1 M HCL)}

$5 \mathrm{ml}$ of test stock solution was taken in a $50 \mathrm{ml}$ volumetric flask, $5 \mathrm{ml}$ of $0.1 \mathrm{M} \mathrm{HCl}$ was added and heated to $80^{\circ} \mathrm{C}$ for 1 hour in a water bath. The flask was removed and allowed to cool at room temperature. Add $5 \mathrm{~mL}$ of $0.1 \mathrm{M} \mathrm{NaOH}$ to neutralize the solution and dilute to volume with diluents and mixed solution.10 $\mathrm{mL}$ of solution was injected into the system and chromatograms were recorded to assess the stability of the sample.

\section{Studies on Alkali degradation (0.1 M NaOH)}

From the test stock solution $5 \mathrm{ml}$ was taken in $50 \mathrm{ml}$ volumetric flask, add $5 \mathrm{ml}$ of $0.1 \mathrm{M} \mathrm{NaOH}$ and heated at $80{ }^{\circ} \mathrm{C}$ for 1 hour on a water bath. The flask was removed from the water bath and allowed to cool at room temperature. Add $5 \mathrm{ml}$ of $0.1 \mathrm{M} \mathrm{HCL}$ to neutralize the solution and diluted to volume with diluents and mixed.10 $\mu 1$ solution were injected in to the system and the chromatograms were recorded to assess the stability of sample.

\section{Studies on Peroxide degradation $\left(0.3 \%\right.$ of $\left.\mathrm{H}_{2} \mathrm{O}_{2}\right)$}

In a $50 \mathrm{ml}$ volumetric flask, $5 \mathrm{ml}$ of 0.3 percent $\mathrm{H} 2 \mathrm{O} 2$ was added to the test stock solution and heated to $80^{\circ}$ $\mathrm{C}$ for 1 hour in a water bath. The flask was removed from the water bath and cooled at room temperature and diluted to volume with diluents and mixed solution.10 $\mu \mathrm{l}$ of solution was injected into the system and chromatograms were collected to evaluate the stability of the sample.

\section{Studies on Hydrolysis degradation}

$5 \mathrm{ml}$ of test solution was taken in a $50 \mathrm{ml}$ volumetric flask and $5 \mathrm{ml}$ of water was added and heat to $80^{\circ} \mathrm{C}$ for 1 hour in a water bath. The flask was withdrawn from the water bath and cooled at room temp and diluted to volume with diluents and mixed. $10 \mu$ solution was injected into the system and the sample stability was measured using chromatograms.

\section{Studies on Thermal degradation $\left(8^{\circ} \mathrm{C} / 48 \mathrm{hrs}\right)$}

To test dry heat degradation, the drug sample was put in oven at $80^{\circ} \mathrm{C}$ for $48 \mathrm{hrs}$. Weight powder equal to 25 $\mathrm{mg}$ of LEV added to $100 \mathrm{ml}$ of volumetric flask for HPLC analysis, add $30 \%$ diluent, sonicate for 15 minutes. Filter the solution through Whatman filter paper no. $41,5.0 \mathrm{ml}$ filtrate pipette into $50 \mathrm{ml}$ of vol. Flask, and finally render to diluent level. $10 \mu$ l solutions was injected into the system, and chromatography was reported to evaluate the sample stability.

\section{Studies on Photolytic degradation}

The drug's photochemical stability was also tested by $48 \mathrm{hrs}$ of exposing product sample powder to UV Radiation. Weight powder equal to $25 \mathrm{mg}$ of LEV added to $100 \mathrm{ml}$ of volumetric flask for HPLC analysis, add $30 \%$ diluent, sonicate for 15 minutes. Filter the solution through Whatman filter paper no. $41,5.0 \mathrm{ml}$ filtrate pipette into $50 \mathrm{ml}$ of vol. Flask, and finally render to diluent level. $10 \mu$ l solutions were injected into the system, and a chromatogram was reported to determine the sample stability.

At each point of the above-mentioned studies the purity of the drug peaks was tested using the peak purity test. And the results are expressed in Table 7 and Fig. 7. $10 \mu \mathrm{l}$ solution was injected into the system and the sample stability was measured using chromatograms. 


\section{Results and Discussion}

\section{The chromatographic conditions are optimized}

Most HPLC methods documented using the C-8 or C18 columns to report. Complex compositions of the mobile phases are also used. Therefore, attempts on the widely used Hypersil BDS C18 column were based on the development of a Simple and Effective method with good resolution. In order to achieve a reasonable separation between drugs and degraded products, different conceptual modifications were attempted. Such improvements included change in mobile phase composition in isocratic elution, as well as gradient modes on different HPLC columns.

The chromatographic optimization conditions Fig 3. The best peak form and maximum separation was achieved with the mobile phase composition of Acetonitrile and Phosphate buffer pH-7.0 (60:40), peak symmetry and reproducibility was obtained with Hypersil BDS C18, $250 \mathrm{~mm}$ and $4.6 \mathrm{~mm}, 5 \mu \mathrm{m}$ column. The optimum wavelength for analyte detection was found to be $230 \mathrm{~nm}$, with a flow rate of $1.0 \mathrm{ml} / \mathrm{min}$ providing optimal separation and peak symmetry. LEV chromatography and MON Fig 3. And Table 1 displays optimized chromatographic state.

\section{Accuracy and precision}

By spiking previously analyzed test solution with additional Placebo at three separate concentration points Table 4, accuracy as recovery was evaluated. Recovery of previously tested drug concentration added test solution was found to be $100.08 \%$ for LEV and $98.9 \%$ for MON with RSD value less than $1 \%$ suggesting that the proposed approach is suitable for simultaneous estimation for both drugs from their combination drug products in the presence of their degradation products. The low RSD values suggest the repeatability and reproducibility of Tables $5 a$ and $5 b$ of the process.

\section{Linearity, LOD and LOQ}

The calibration plot was linear across the examined concentration range $(12.56-37.68 \mu \mathrm{g} / \mathrm{ml})$ for LEV, $(23.78-71.20 \mu \mathrm{g} / \mathrm{ml})$ for MON, respectively. The average correlation coefficient $\mathrm{R} 2=0.999$ was derived from the regression analysis to both drugs with \% RSD values as well as 2.0 around the concentration ranges tested. The LOD which generated the necessary accuracy and precision was found to be $0.079 \mu \mathrm{g} / \mathrm{ml}$ LEV and $0.156 \mu \mathrm{g} / \mathrm{ml} \mathrm{MON}$. The corresponding \% of RSD values in Table $3 \mathrm{c}$ was $0.1 .00 \%$. The LOQ for LEV and MON was $0.239 \mu \mathrm{g} / \mathrm{ml}, 0.473 \mu \mathrm{g} / \mathrm{ml}$, respectively. The findings of the Regression suggest that the process was linear in the concentration range tested and can be used to detect and measure LEV and MON within a very large range of concentrations. Illustration. 5A - B show LEV and MON linearity graphs, respectively.

\section{Selectivity and specificity}

In each study the specificity is tested by analyzing blank and placebo samples for any interfering peaks. Owing to the existence of some other excipient the precision of the approach was assessed with respect to intervention. The figures indicate clearly distinguishing the chosen products. Fig. 6a and b displays a chromatogram of a blank and working sample solution for placebo. No interfering peaks occurred during LEV and MON retention times.

\section{Robustness}

Robustness Results Table 8. The elution order and resolution were not substantially impacted for all materials. RSD of peak areas was found to be far below the $2.0 \%$ mark.

\section{System suitability}

The parameters of suitability for the system were found to fall within acceptance criteria. Good peak with resolution between two drugs is $>1.5$, asymmetric factor $<2$ indicates stronger separation of the drugs. A number of theoretical plates, tailing factor, resolution, retention time, and area were the parameters measured for device suitability. Table 7 displays progress.

\section{Degradation studies}

The results of the stability studies were shown in Table 9 and Fig 6 a-f. 
Table 9: LEC-MON stability studies

\begin{tabular}{|l|c|c|}
\hline \multicolumn{1}{|c|}{ Stress conditions } & LEV & MON \\
\hline & \% degradation & \% degradation \\
\hline Acid $/ 0.1 \mathrm{M} \mathrm{HCL} / 80^{\circ} \mathrm{C}$ reflux $/ 3 \mathrm{hrs}$ & 10.62 & 12.27 \\
\hline Basic $/ 0.1 \mathrm{M} \mathrm{NaOH} / 80^{\circ} \mathrm{C}$ reflux $/ 3 \mathrm{hrs}$ & 5.11 & 5.90 \\
\hline Oxidizing $/ 0.3 \% \mathrm{H}_{2} \mathrm{O}_{2} / \mathrm{cool}$ at $\mathrm{RT} / 3 \mathrm{hrs}$ & 3.59 & 1.02 \\
\hline Hydrolysis $/ \mathrm{Water} / 80^{\circ} \mathrm{C} / 3 \mathrm{hrs}$ & 8.75 & 2.77 \\
\hline Thermal $/ 80^{\circ} \mathrm{C} / 48 \mathrm{hrs}$ & 0.75 & 2.63 \\
\hline Photolysis $/ \mathrm{UV}$ light & 5.91 & 27.84 \\
\hline
\end{tabular}

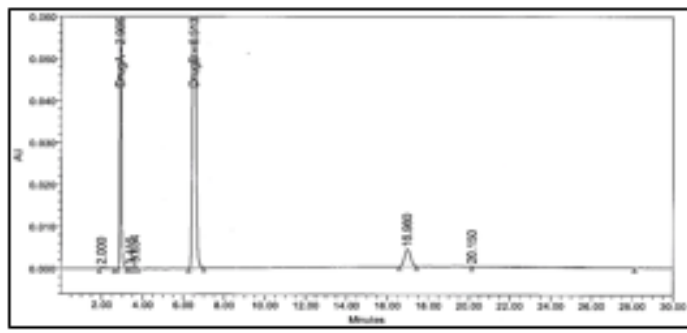

(a)

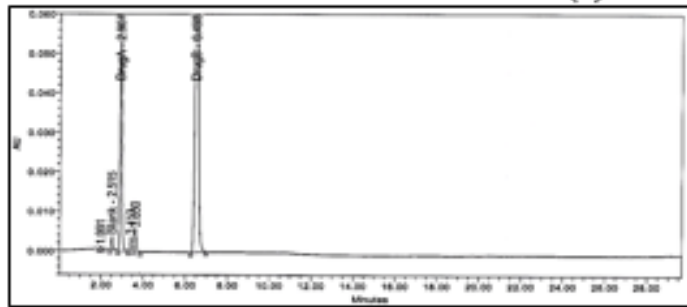

(c)

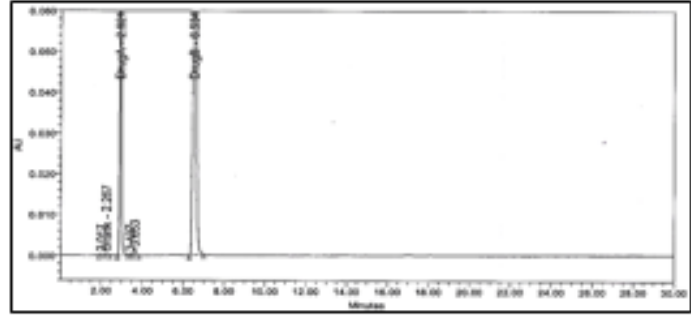

(e)

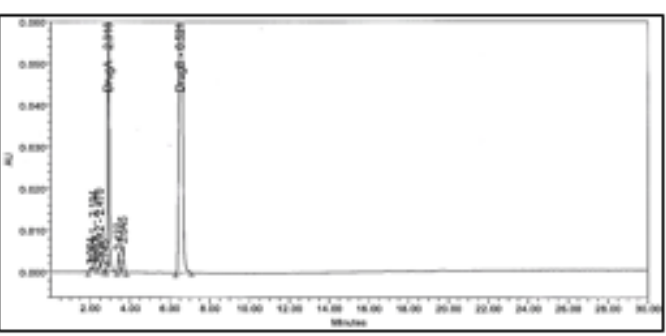

(b)

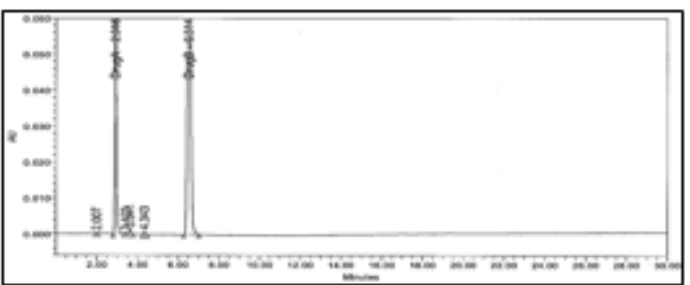

(d)

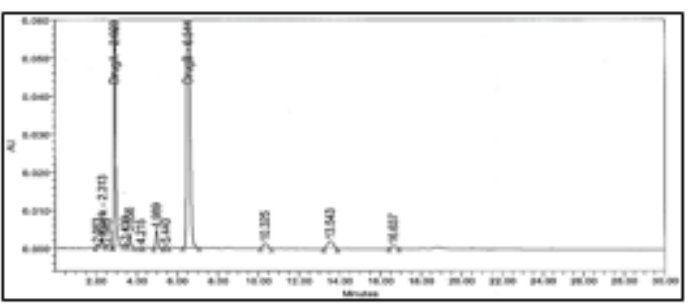

(f)

Fig. 6: (a-f): Degraded chromatograms - (a) Acid degradation (b) Alkali degradation (c) Oxidation degradation (d)Hydrolytic degradation (e) Thermal degradation (f) Photolytic degradation.

Acid hydrolysis (Fig. 6a)

$10.62 \%$ of LEV and $12.27 \%$ of MON were degraded upon completion of acid degradation studies.

Base hydrolysis (Fig. 6b)

$5.11 \%$ of LEV and $5.90 \%$ of MON were degraded upon completion of base degradation studies.

Peroxide hydrolysis (Fig. 6c)

$3.59 \%$ of LEV and $1.02 \%$ of MON were degraded upon completion of peroxide degradation studies.
Hydrolytic degradation (Fig. 6d)

$8.75 \%$ of LEV and $2.77 \%$ of MON were degraded upon completion of hydrolytic degradation studies.

Thermal degradation (Fig. 6e)

$0.75 \%$ of LEV and $2.63 \%$ of MON were degraded upon completion of thermal degradation studies.

Photolytic degradation (Fig. 6f)

$5.91 \%$ of LEV and $27.84 \%$ of MON were degraded upon completion of photolytic degradation studies. 
Statistical analysis showed that the method proposed was simple, accurate and reliable when compared to the reported method. ${ }^{3}$

\section{Conclusion}

A simple, accurate, commercial and time depleting RPHPLC method was developed by using Hypersil BDS $\mathrm{C} 18(250 \times 4.6 \mathrm{~mm} ; 5 \mu \mathrm{m})$ column, at $30^{\circ} \mathrm{C}$ temperature using mobile phase Disodium hydrogen orthophosphate dihydrate as Buffer ( $\mathrm{pH} 7.0$ with OPA) : Acetonitrile in $40: 60 \% \mathrm{v} / \mathrm{v}$ proportion at $1 \mathrm{ml} / \mathrm{min}$ flow rate. Detection was carried out at $230 \mathrm{~nm}$ found to give sharp, well defined peaks with good symmetry $t_{R} 3.06 \pm 0.5 \mathrm{~min}$ and $6.76 \pm 0.5 \mathrm{~min}$ for LEV and MON respectively. The method was validated with respect to various parameters such as linearity, range, precision, accuracy, robustness etc. The linear calibration curve for LEV was obtained at concentration range $12.56-37.68 \mu \mathrm{g} / \mathrm{ml}$ with $\mathrm{r}^{2}$ 0.9998. For MON 23.73-71.20 $\mu \mathrm{g} / \mathrm{ml}$ with $\mathrm{r}^{2}$ 0.9998. The proposed method was employed for the forced degradation studies of LEV and MON. The degradation pathways under different conditions studied. For LEV and MON show 30-40\% degradation for oxidation $\left(3 \% \mathrm{H}_{2} \mathrm{O}_{2}\right.$ for $\left.1 \mathrm{hrs}\right), 20-25 \%$ degradation for U.V-light (48 hrs). So it can be concluded that both drugs were extremely labile to oxidation as well as photolytic condition. Found to be stable for base, neutral and dry heat degradation as less than $10 \%$ of drugs were degraded. 10-15\% LEV and MON was degraded in acidic condition, So it is concluded that both drugs were unstable to acid conditions.

The developed HPLC method is simple, accurate, time depleting, reproducible and stability indicating for quantitative analysis of LEV and MON in pharmaceutical dosage form, without any interference from the excipients and in the presence of its acidic, alkaline, oxidative, thermal, neutral and photolytic degradation products. The chromatographic method was validated in accordance with the ICH guidelines. Statistical tests indicate that the proposed HPLC method reduces the duration of the analysis and appears to be equally suitable for routine determination of LEV and MON in pharmaceutical dosage form in quality control laboratories where economy and time are essential.
This study is typical example of development of stability indicating assay, it is one of the rare studies where forced decomposition was done under all different suggested conditions and the degradation products were resolved. As the method separates the drug from its degradation products, it can be employed as a stability indicating method

\section{Acknowledgment}

The author are extremely thankful to Dr. Vikram S. Gharge, Associate Director of Research and Development, Emcure Pharmaceuticals Ltd. Bhosari, Pune (M.S.), India for the provision of facilities and gift samples for research purposes. Also thankful to Principal, H. R. Patel Institute of Pharmaceutical Education and Research. Shirpur, Dhule (M.S), India.

\section{Source of Funding}

None.

\section{Conflict of Interest}

None.

\section{References}

1. O'Neil MJ, Smith A, Heckelman PE, Budavari S, "The Merck Index-An Encyclopedia of Chemicals, Drugs, and Biologicals. Whitehouse Station, NJ: Merck and Co," Inc, 2001:767p

2. Raghu MS, Basavaiah K, "Optimized and validated spectrophotometric methods for the determination of levocetirizine in pharmaceuticals based on charge transfer reaction," J Assoc Arab Univ Basic Appl Sci 2012;12(1):33-41.

3. Ishaq BM, Prakash K, Mohan G, Muneer S, Ahad H, "RPHPLC method for simultaneous estimation of levocetirizine dihydrochloride and montelukast sodium in tablets," Indian EJ Pharma Sci 2015;1(1):18-20.

4. I. P Commission, "Indian Pharmacopoeia 2007," ed: Indian Pharmacopoeia Commission, 2007.

5. Choudhari V, Kale A, Abnawe S, Kuchekar B, Gawli V, Patil N, "Simultaneous determination of montelukast sodium and levocetirizine dihydrochloride in pharmaceutical preparations by ratio derivative spectroscopy," Int J Pharm Tech Res 2010;2(1):4.

6. Gupta M, Gupta N, Chauhan BS, Pandey S, "Fast disintegrating combination tablet of taste masked levocetrizine dihydrochloride and montelukast sodium: formulation design, development, and characterization," J Pharm 2014:2014. 
7. Somkuwar S, Pathak A, "Simultaneous estimation of levocetirizine dihydrochloride and montelukast sodium by RP-HPLC Method," Pharm 2012;1:90-4.

8. Devalia J, Hanotte F, Baltes E, De Vos C, "A randomized, double-blind, crossover comparison among cetirizine, levocetirizine, and ucb 28557 on histamineinduced cutaneous responses in healthy adult volunteers," All 2001;56(1):50-7.

9. S. C. Sweetman, Martindale: the complete drug reference. Pharmaceutical press London, 2009.

10. Budavari S, O'Neil MJ, Smith A, Heckelman PE, The merck index. Merck Rahway, NJ, 1989.

11. Vekaria H, Limbasiya V, Patel P, "Development and validation of RP-HPLC method for simultaneous estimation of montelukast sodium and fexofenadine hydrochloride in combined dosage form," J Pharm Res 2013;6(1):134-9.

12. Singh R, Saini P, Mathur S, Singh G, Lal B, "Development and validation of a RP-HPLC method for estimation of montelukast sodium in bulk and in tablet dosage form," Indian J Pharm Sci 2010;72(2):235.

13. Sharma S, Sharma M, Kohli D, Sharma A, "Development and validation of TLC-densitometry method for simultaneous quantification of montelukast sodium and levocetirizine dihydrochloride pharmaceutical solid dosage form," Der Pharm Lettre 2010;2(1):489-94.

14. Rathore A, Sathiyanarayanan L, Mahadik K, "Development of Validated HPLC and HPTLC Methods for Simultaneous Determination of Levocetirizine Dihydrochloride and Montelukast Sodium in Bulk Drug and Pharmaceutical Dosage Form. Pharm Anal Acta 2010;1:106.

15. Sankar A, Baskar G, Nagavalli D, Anandakumar K, Vetrichelvan T, "Simultaneous Estimation of Montelukast Sodium and Levocetirizine Hydrochloride from Tablet Dosage Form," Res J Pharm Technol 2009;2(4):743-5.
16. Ashokkumar S, Raja MS, Perumal P, "RP-HPLC method development and validation for simultaneous estimation of montelukast sodium and levocetirizine dihydrochloride," Int J Pharm Res 2009;1(4):8-12.

17. ICH T, "Validation of Analytical Procedures: Methodology (CPMP/ICH/281/95). Step 4. Consensus Guideline," ed: The European Agency for the Evaluation of Medicinal Products, London, UK, 1996.

18. Mastanamma S, Chandini S, Reehana S, Saidulu P, "Development and validation of stability indicating RPHPLC method for the simultaneous estimation of Sofosbuvir and Ledipasvir in bulk and their combined dosage form," Future J Pharm Sci 2018;4(2):116-23.

19. Patel MG, Patil PO, Bari SB, "Validated RP-HPLC method for simultaneous estimation of Metformin Hydrochloride and Benfotiamine in bulk drug and in pharmaceutical dosage form," Int J Anal Bioanalytical Chem 2012;2(3):196-200.

20. I. H. T. Guideline, "Validation of analytical procedures: text and methodology Q2 (R1)," in International conference on harmonization, Geneva, Switzerland, 2005, vol. 11.

21. I. H. T. Guideline, "Stability testing of new drug substances and products," Q1A (R2), current step, 2003;4;1-24.

22. C. Runja, P. Ravikumar, and S. R. Avanapu, "A Validated Stability Indicating RP-HPLC Method Development and Validation for Simultaneous Estimation of Aliskiren Hemifumarate and Amlodipine Besylate in Pharmaceutical Dosage Form," Chromatography Res Int 2014:2014.

How to cite: Sonawane JK, Patil DA, Jadhav BS, Jadhav SL, Patil PB. Stability Indicating RP-HPLC method development and validation for simultaneous quantification of antihistaminic \& antiasthmatic drug in bulk and tablet dosage form. $J$ Pharm Biol Sci 2020;8(1):12-22. 